\title{
Review
}

\section{Praperlakuan secara Hidrotermal Limbah Lignoselulosa untuk Produksi Bioetanol Generasi Kedua Pretreatment of Lignocellulose Wastes Using Hydrothermal Method for Producing Second Generation Bioethanol}

\author{
Al-Arofatus Naini ${ }^{a}$, Nurwahdah ${ }^{a}$, Ratri Yuli Lestari ${ }^{b, c}$, Sunardia,c* \\ ${ }^{a}$ Chemistry Department, Faculty of Mathematics and Natural Sciences, \\ Lambung Mangkurat University, Banjarbaru 70714, Indonesia \\ ${ }^{\mathrm{b}}$ The Institution of Research and Standardization of Industry Banjarbaru, \\ Jalan Panglima Batur Barat No. 2 Banjarbaru 70711, Kalimantan Selatan, Indonesia \\ 'Wetland Resources for Environmental Sustainability Research Group, \\ Faculty of Mathematics and Natural Sciences, Lambung Mangkurat University, \\ Banjarbaru 70714, Indonesia \\ *Email: sunardi@ulm.ac.id
}

Diterima 30 Juli 2018 Disetujui 05 Desember 2018 Diterbitkan 29 Desember 2018

\begin{abstract}
ABSTRAK
Bioetanol generasi kedua dengan bahan baku selulosa yang berasal dari berbagai material biomassa merupakan salah satu bentuk terbaru alternatif terbarukan. Potensi limbah selulosa dari material kayu dan non kayu merupakan sumber daya alam yang paling melimpah di muka bumi, terbarukan, dan murah. Saat ini pengembangan bioetanol generasi kedua masih belum optimal dilakukan karena adanya berbagai hambatan, terutama proses praperlakuan untuk menghilangkan lignin sehingga proses konversi selulosa menjadi gula pereduksi lebih optimal. Metode hidrotermal merupakan salah satu metode praperlakuan lignoselulosa yang saat ini banyak dikembangkan karena metode ini relatif murah dan ramah lingkungan karena hanya menggunakan air sebagai pelarut. Metode hidrotermal yang dilakukan pada temperatur dan tekanan tinggi dalam waktu yang relatif singkat mampu mendekonstruksi struktur lignoselulosa sehingga menghasilkan struktur baru yang memudahkan enzim selulase mengakses selulosa untuk proses hidrolisis. Dalam tulisan ini dibahas tentang perkembangan metode hidrotermal untuk proses praperlakuan lignoselulosa untuk meningkatkan produksi bioetanol generasi kedua. Beberapa aspek yang dikaji antara lain perubahan struktur, komposisi kimia, dan kristalinitas lignoselulosa sebelum dan setelah proses hidrotermal serta pengaruhnya terhadap produksi gula pereduksi dan bioetanol generasi kedua, sehingga metode hidrotermal dapat digunakan dan dikembangkan sebagai metode yang efisien dan murah untuk perlakuan awal terhadap limbah lignoselulosa dalam upaya peningkatan produk bioetanol yang dihasilkan.
\end{abstract}

Kata kunci : hidrotermal, praperlakuan, lignoselulosa

\section{ABSTRACT}

The second generation of bioethanol derived from various cellulosic biomass materials is one of the latest renewable energy as the alternative of fossil fuel. The cellulosic waste based wood and non-wood materials are the most abundant natural resource on the earth, renewable, and inexpensive. Currently, second generation bioethanol development is still not optimally done due to various obstacles, especially the pretreatment process to eliminate lignin, influencing the conversion process of cellulose into reducing sugar. Hydrothermal method is one of lignocellulose pretreatments, which is widely developed because this method is relatively cheap and environmentally friendly 
with the utilization of water-based solvent. Hydrothermal methods performed at high temperature and pressure in a relatively short time are able to deconstruct the lignocellulose structure that enables cellulase enzymes to access cellulose for hydrolysis. This study discussed about the development of hydrothermal method for lignocellulose pretreatment process to increase production of second-generation bioethanol. Some aspects studied in this research were structural change, chemical composition, lignocellulosic crystallinity before and after hydrothermal processes, and hydrothermal effect on the production of reducing sugars. Hydrothermal method could be used and developed as an efficient and cheap method as the first treatment of lignocellulose waste in attempt to increase the production of bioethanol.

Keywords : hydrothermal, pretreatment, lignocellulose.

\section{PENDAHULUAN}

Sampai saat ini bahan bakar fosil masih menjadi tumpuan dalam konsumsi baik industri maupun transportasi. Untuk mengatasi keadaan yang tidak seimbang antara produksi dengan konsumsi bahan bakar fosil, saat ini telah banyak dilakukan kajian tentang proses produksi bahan bakar terbarukan yang efisien dan ramah lingkungan. Bioetanol generasi kedua merupakan salah satu energi terbarukan yang bersumber pada material biomassa non pangan (Carvahlo, Jose, \& Jorge, 2017). Limbah lignoselulosa adalah salah satu residu sumber biomassa yang keberadaannya melimpah, tidak bernilai jual, dan tidak bersaing dengan sumber bahan pangan. Lignoselulosa memiliki kandungan tiga polimer utama berupa lignin, selulosa dan hemiselulosa (Petchpradap, Yoshida, Charinpanitkul, \& Matsumura, 2009). Kendala yang banyak dialami pada saat konversi lignoselulosa menjadi bioetanol adalah proses praperlakuan penghilangan lignin sehingga produksi bioetanol dari lignoselulosa belum optimal (Shuai et al., 2010).

Metode hidrotermal adalah salah satu proses praperlakuan untuk konversi lignoselulosa menjadi bioetanol generasi kedua. Proses praperlakuan menggunakan metode hidrotermal dapat meningkatan produk gula pereduksi hasil hidrolisis yang akan dikonversi menjadi bioetanol melalui proses enzimatis (Ninomiya et al., 2013). Semakin banyak gula pereduksi yang dihasilkan maka akan meningkatkan konversi bioetanol. Hidrotermal juga merupakan metode yang ramah lingkungan karena memanfaatkan air sebagai pelarut dengan mengkondisikan air berada pada suhu titik sub-kritis, sehingga air akan berperilaku seperti asam basa dalam mengkatalisis suatu reaksi (Lei, Cybulska, \& Julson, 2013). Praperlakuan hidrotermal dapat dilakukan dengan berbagai macam metode yaitu auto-hidrolisis, hotcompressed water treatment, hydrothermal liquefaction, prahidrolisis dan praperlakuan air dengan keadaan sub-kritis (Jin et al., 2016). Telaah ini bertujuan untuk mengetahui perkembangan proses hidrotermal sebagai praperlakuan pada lignoselulosa untuk meningkatkan produksi bioetanol generasi kedua.

\section{KONVERSI LIMBAH LIGNOSELULOSA MENJADI BIOETANOL GENERASI KEDUA}

Biomassa lignoselulosa merupakan sumber daya alam terbarukan yang keberadaannya sangat melimpah karena berasal dari tanaman yang memiliki struktur batang yang keras dan tidak bersaing dengan bahan pangan. Secara umum, tingkat pertumbuhan biomassa lignoselulosa per tahun sebesar $1 \times 10^{11}$ ton (Smeets, Faaij, Lewandowski, \& Turkenburg, 2007). Untuk konversi lignoselulosa menjadi etanol komponen penyusun harus dipecah menjadi selulosa, hemiselulosa dan lignin yang akan dilanjutkan proses hidrolisis (Mood et al., 2013). Reaksi yang terjadi menggunakan perlakuan hidrotermal adalah hidrolisis dengan beberapa reaksi lain yang mengikuti seperti, dekarboksilasi, dehidrasi, aromatisasi, polimerasi dan kondensasi (Reza, 2013). 


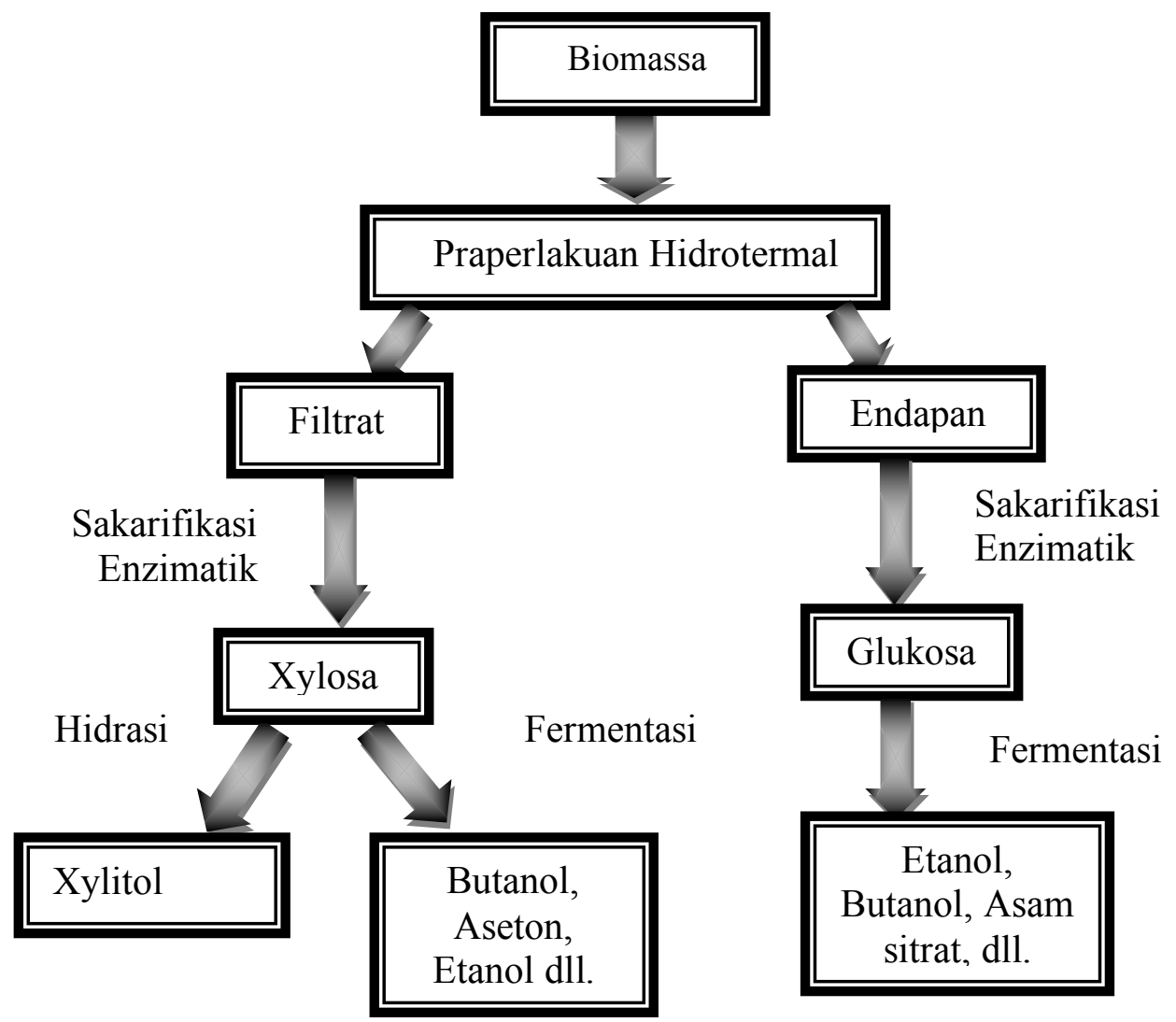

Gambar 1. Skema Produk yang Dapat Diperoleh Setelah Proses Hidrotermal Biomassa Lignoselulosa (Bobleter, 1994).

Proses hidrotermal pada selulosa akan menghasilkan residu dan cairan filtrat biasa disebut proses "biomassa fraksinasi". Residu dan filtrat yang dihasilkan dilanjutkan dengan proses sakarifikasi secara enzimatis menghasilkan glukosa dan xylosa. Glukosa dilakukan fermentasi menghasilkan asam sitrat, butanol sebagai produk samping dan etanol sebagai produk utama. Sedangkan xylosa dari filtrat dapat diolah menjadi xylitol melalui reaksi hidrasi dan menjadi etanol, butanol, aseton melaui proses fermentasi (Bobleter, 1994). Pada praperlakuan hidrotermal, tidak perlu pemisahan lignin, karena lignin akan terurai menjadi bentuk poliol seperti katekol, fenol, dan o-kresol dan tidak menghalangi akses enzim dalam hidrolisis selulosa (Wahyudiono, Machmudah, \& Goto, 2013). Skema alur produk yang dihasilkan dari proses praperlakuan pada lignoselulosa dapat dilihat pada Gambar 1.

\section{MEKANISME PRAPERLAKUAN METODE HIDROTERMAL}

Metode hidrotermal memberikan
perlakuan berupa reaksi katalitik menggunakan ion-ion yang dihasilkan oleh pelarut air (Garrote, DomõÂnguez, \& Parajo, 1999). Air pada metode hidrotermal akan berada pada dua kondisi yaitu air pada titik super kritik dan air pada titik subkritik. Air pada kondisi super kritik berperan sebagai reaktan yaitu melarutkan kristal selulosa dalam bahan baku biomassa yang digunakan. Sedangkan air berada pada titik sub-kritik sekitar $150^{\circ} \mathrm{C}-230^{\circ} \mathrm{C}$ akan berperan sebagai katalis asam atau basa dari ion $\mathrm{H}^{+}$dan $\mathrm{OH}^{-}$yang dihasilkan air dalam suatu reaksi hidrotermal (Sarwono, Arief, Rizka, Hendris, \& Fatah, 2016).

Mekanisme yang terjadi pada saat proses reaksi hidrotermal, pertama konstanta ionisasi air (Kw) akan mengalami kenaikan dengan naiknya temperatur air saat berada pada kondisi sub-kritik $\left(100^{\circ} \mathrm{C}\right.$ - 
$374^{\circ} \mathrm{C}$ ) (Ando et al., 2000). Nilai konstanta ionisasi air $(\mathrm{Kw})$ pada suhu $25^{\circ} \mathrm{C}$ adalah $10^{-14}$, naik menjadi $10^{-12}$ pada suhu $100^{\circ} \mathrm{C}$ dan pada suhu $270^{\circ} \mathrm{C}$ nilai konstanta ionisasi air $(\mathrm{Kw})$ menjadi $10^{-11,05}$. Nilai konstanta ionisasi adalah kemampuan air membentuk ion-ion. Meningkatnya nilai Kw, maka ion $\mathrm{H}^{+}$dan $\mathrm{OH}^{-}$akan semakin banyak terbentuk (Marshall, 1981). Terbentuknya ion-ion $\mathrm{H}^{+}$pada keadaan sub-kritik air sebagai pelarut pada praperlakuan hidrotermal akan bersifat seperti pelarut asam atau basa lemah. Asam atau basa dapat mengkatalisis reaksi hidrolisis ikatan ester ataupun ikatan eter (Garrote et al., 1999), sehingga air dapat berperan sebagai reaktan maupun katalis dalam praperlakuan hidrotermal.

Reaksi katalisis ion $\mathrm{H}^{+}$dan $\mathrm{OH}^{-}$yang terbentuk dari molekul air ketika pada kondisi HTW (Hot Temperature Water) adalah memutus ikatan eter pada glikosida yang menghubungkan monomer penyusun selulosa, hemiselulosa dan lignin pada biomassa. Hidrolisis ikatan eter cellobioses pada selulosa akan terbentuk gula pereduksi yang akan dikonversi menjadi bioetanol (Ruiz, Cara, Manzanares, Ballesteros, \& Castro, 1999). Ikatan eter heterosiklik pada hemiselulosa adalah salah satu ikatan yang mudah di pecah dengan keberadaan ion hidronium $\left(\mathrm{H}_{3} \mathrm{O}^{+}\right)$ dari molekul air. Hasil pemutusan ikatan tersebut akan menghasilkan oligosakarida dan membentuk gugus asetil dari fraksi hemiselulosa. Keberadaan gugus asetil tersebut akan mengkatalisis reaksi pemutusan ikatan glikosida pada molekul polisakarida. Gugus asetil tersebut memiliki fungsi katalisis reaksi hidrolisis lebih kuat dari ion $\mathrm{H}_{3} \mathrm{O}^{+}$dari molekul $\mathrm{H}_{2} \mathrm{O}$. Asamasam organik yang lain akan terbentuk seperti asam uronik pada fraksi hemiselulosa, akan tetapi keberadaannya tidak stabil. Praperlakuan hidrotermal juga dapat memecah ikatan eter dan ester pada struktur lignin yang menghubungkan antar monomer, yang terjadi pada suhu $120^{\circ} \mathrm{C}$ $200^{\circ} \mathrm{C}$ (Garrote et al., 1999). Lignin sangat mengganggu dalam proses konversi biomassa menjadi bioetanol, sehingga lignin harus dihilangkan dengan proses praperlakuan sebelum proses hidrolisis agar terbentuk unit gula pereduksi sehingga proses enzimatis untuk menghasilkan etanol didapatkan hasil yang optimum (Sarwono et al., 2016).

\section{PENGARUH PRAPERLAKUAN HIDROTERMAL TERHADAP STRUKTUR LIGNOSELULOSA}

Praperlakuan merupakan tahap yang sangat penting dan menjadi hambatan dalam produksi bioetanol yang berasal dari lignoselulosa. Pengaruh praperlakuan hidrotermal terhadap struktur lignoselulosa memiliki perubahan sifat masing-masing yang terdiri atas selulosa, hemiselulosa dan lignin. Tujuan proses praperlakuan adalah memecah struktur kristalin agar memudahkan proses hidrolisis menjadi gula pereduksi maupun proses sakarifikasi enzimatis untuk menghasilkan bioetanol generasi kedua.

\subsection{Pengaruh Praperlakuan Hidrotermal terhadap Selulosa \\ Selulosa merupakan komponen utama dalam struktur lignoselulosa} (O'Sullivan, 1997). Kristalinitas pada selulosa menyebabkan proses pemecahan struktur selulosa sulit dilakukan meskipun telah dilakukan pemanasan dengan waktu yang sangat lama (Xiao et al., 2014). Metode praperlakuan hidrotermal dapat memutus ikatan hidrogen intra dan inter molekul pada selulosa, sehingga selulosa dengan fasa amorf dapat diperoleh relatif lebih mudah dibanding tanpa melewati proses praperlakuan menggunakan metode hidrotermal (Oh, Yoo, Shin \& Seo, 2005). Beberapa hasil penelitian tentang perubahan selulosa setelah dilakukan proses hidrotermal ditunjukkan pada Tabel 1. 
(Review) Praperlakuan secara Hidrotermal Limbah ......Al-Arofatus Naini et al.
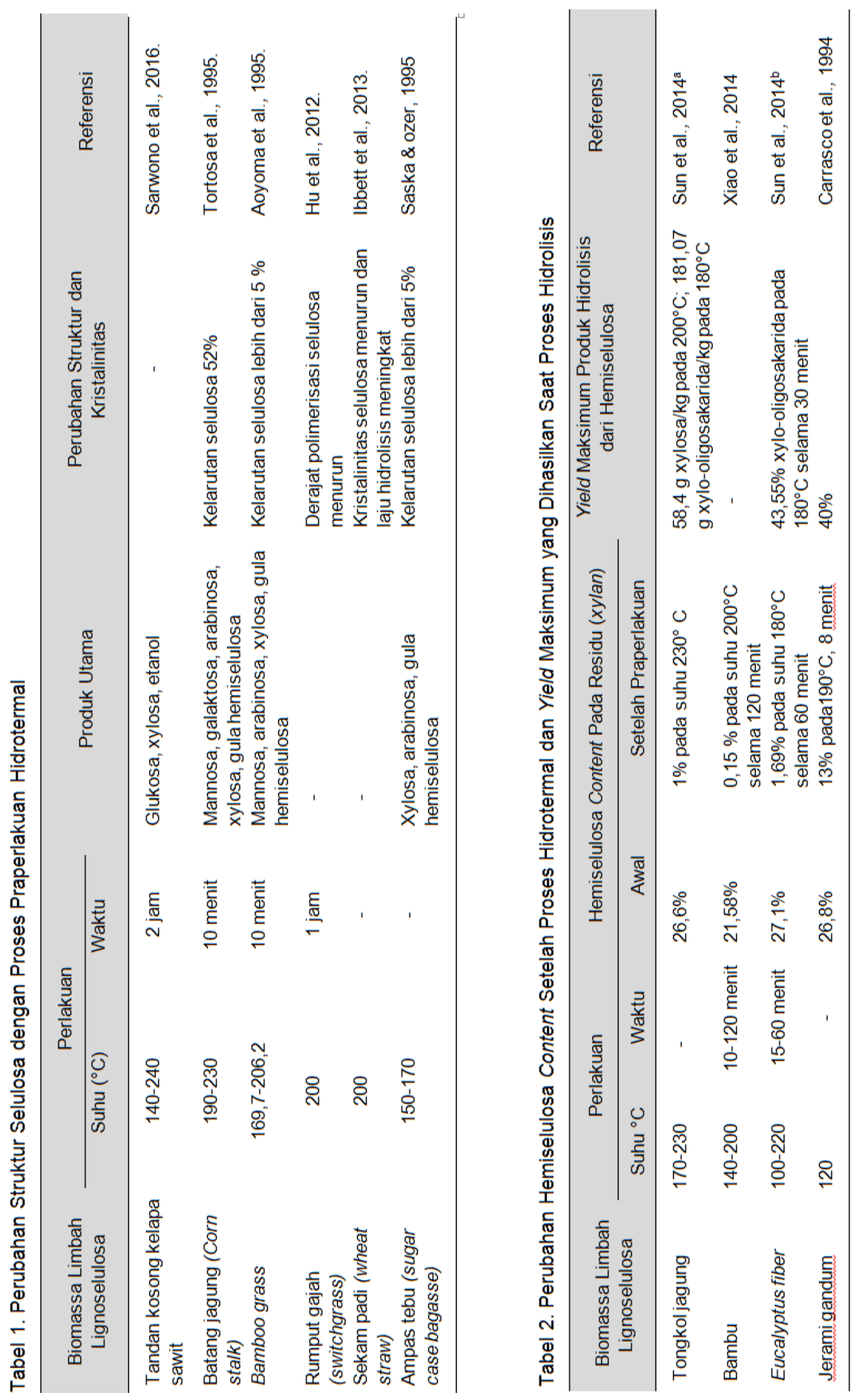

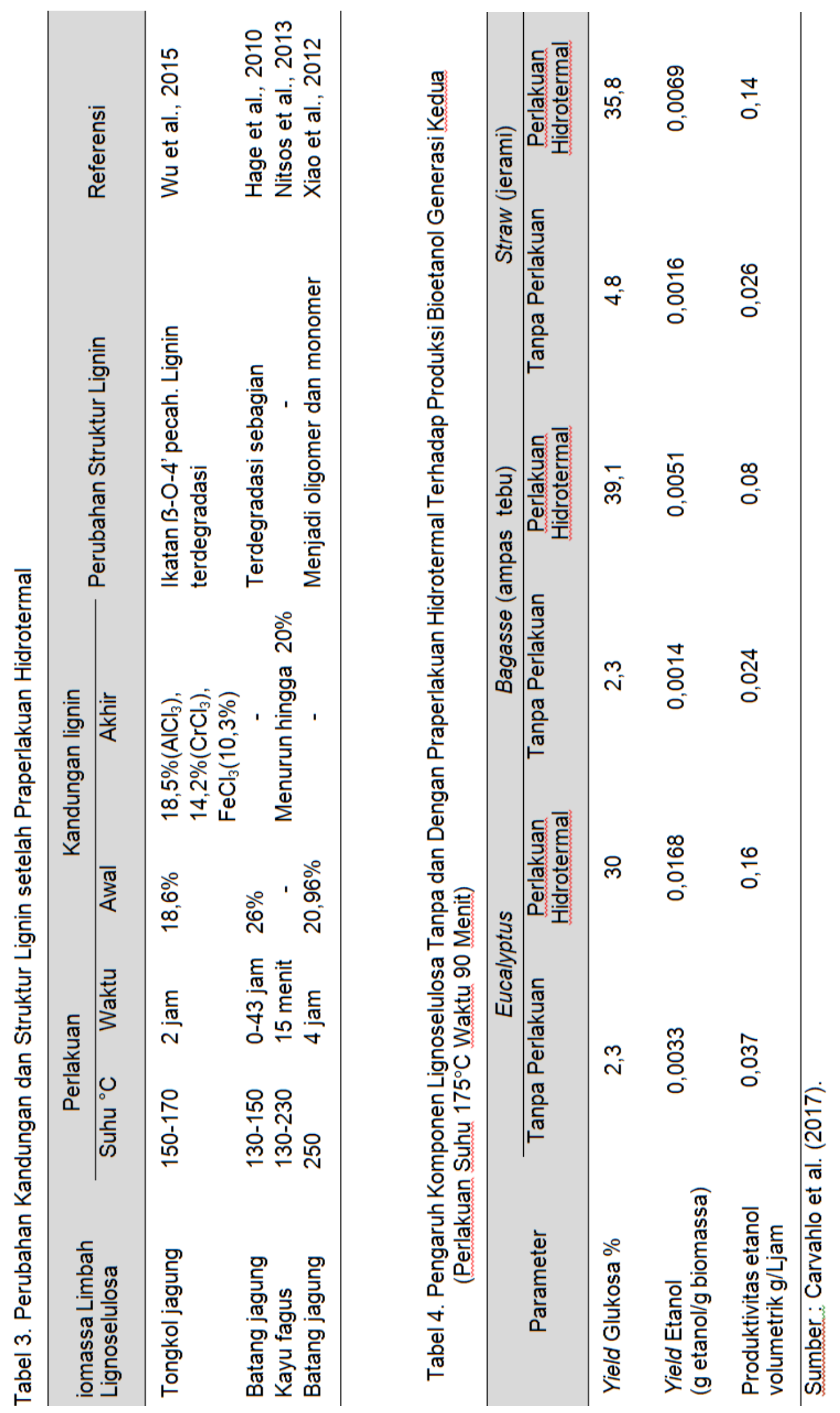


\subsection{Pengaruh Praperlakuan Hidrotermal terhadap Hemiselulosa}

Hemiselulosa adalah komponen utama kedua (15-23\%) penyusun lignoselulosa. Hemiselulosa adalah karbon rantai lima $\mathrm{C}_{5}$ (pentosa) atau gula siklik rantai $\mathrm{C}_{5}$ (furanosa) (Girio et al., 2010). Hemiselulosa memiliki fasa amorf dengan xylosa dan glukomannosa sebagai komponen utama penyusun polimer hemiselulosa. Sifat amorf dari hemiselulosa menjadikan proses dekomposisi dari hemiselulosa relatif lebih mudah daripada selulosa (Tune \& Heiningen, 2011). Menurut Garrote et al. (1999) hemiselulosa mulai larut pada temperatur $>150^{\circ} \mathrm{C}$. Proses dekomposisi hemiselulosa juga menghasilkan asam asetat dan asam glukoronik yang berperan sebagai sumber $\mathrm{H}^{+}$dalam proses dekomposisi metode hidrotermal dan beberapa asam organik lainnya yang hanya terbentuk sementara. Pada proses hidrotermal hemiselulosa adalah bagian yang terdekomposisi terlebih dahulu kemudian diikuti oleh lignin (Costa et al., 2014). Beberapa penelitian memberikan informasi terkait perubahan hemiselulosa yang dihasilkan saat proses hidrolisis (Tabel 2).

\subsection{Pengaruh Praperlakuan Hidrotermal terhadap Lignin}

Lignin adalah struktur yang

melindungi fase kristalin dan fase amorf pada biomassa lignoselulosa (Moiser et al., 2005). Metode hidrotermal dilakukan agar lignin dapat terdekomposisi secara maksimal. Lignin adalah polimer yang terdiri dari tiga jenis monomer fenil propionik alkohol yaitu konifer alkohol, pkumaril alkohol dan sinapsil alkohol, ketiga jenis monomer tersebut memiliki pola substitusi yang berbeda. Lignin terhubung ikatan eter (a-O-4' dan B-O-4') antar monomer (Zhao, Quan, \& Fan, 2013). Metode hidrotermal dapat memecah ikatan ß-O-4' dan ikatan eter dengan katalis asam sehingga proses depolimerisasi dapat terjadi (Hu, Jung, \& Ragauskas, 2012). Perubahan komposisi lignin akibat proses hidrotermal ditunjukkan pada Tabel 3.

\section{PENGARUH HIDROTERMAL LIGNOSELULOSA PENINGKATAN BIOETANOL GENERASI KEDUA \\ PRAPERLAKUAN BIOMASSA TERHADAP PRODUKSI}

Bioetanol adalah bahan bakar yang diproduksi dari biomassa, sebagai pengganti minyak bumi. Bioetanol generasi kedua adalah bahan bakar yang berasal dari biomassa non pangan yaitu lignoselulosa. Proses praperlakuan dibutuhkan sebagai tahap awal konversi biomassa menjadi bioetanol. Metode hidrotermal menjadi salah satu alternatif metode praperlakuan biomassa lignoselulosa sebagai tahap awal proses dekomposisi lignoselulosa agar dihasilkan bioetanol yang maksimal terhadap suatu material lignoselulosa (Carvahlo et al., 2017). Tabel 4 menunjukkan perbedaan yield gula pereduksi dan etanol setelah praperlakuan secara hidrotermal.

Data pada Tabel 4 menunjukkan bahwa dengan adanya praperlakuan hidrotermal produk gula pereduksi meningkat relatif signifikan pada jenis biomassa yang sama. Semakin banyak glukosa, yield etanol akan meningkat dan produktivitas etanol secara volumetrik juga akan meningkat. Sehingga metode hidrotermal dapat digunakan sebagai metode yang dapat meningkatkan produksi bioetanol ramah lingkungan dan murah karena menggunakan air sebagai pelarut. Disisi lain, pencemaran lingkungan akibat dampak penggunaan bahan kimia juga dapat dikurangi.

\section{KESIMPULAN DAN SARAN}

Metode hidrotermal adalah metode perlakuan awal yang menggunakan air sebagai pelarut sehingga disebut metode yang ramah lingkungan, murah dan efisien untuk meningkatkan produksi bioetanol generasi kedua dari biomassa lignoselulosa. Hidrotermal mampu menggangu ikatan hidrogen intra dan inter molekul menjadikan fase amorf pada selulosa meningkat. Bagian hemiselulosa memiliki tingkat kelarutan hingga 95\% dan lignin sekitar $1 \%$ pada suhu $150^{\circ} \mathrm{C}-230^{\circ} \mathrm{C}$ 
pada metode hidrotermal. Sehingga diharapkan metode hidrotermal dapat digunakan dan dikembangkan sebagai metode praperlakuan awal dalam mendekonstruksi struktur biomassa limbah lignoselulosa dalam upaya peningkatan produksi bioetanol generasi kedua yang dihasilkan.

\section{DAFTAR PUSTAKA}

Ando, H. Sakaki, T., Kokusho. T., Shibata. M., Uemura. Y., \& Hatate. Y. (2000). Decomposition Behavior of Plant Biomass in Hot-Compressed Water. Industrial and Engineering Chemistry Research, 39(10), 3688-3693.

Aoyoma, M., Seki, K. \& Saito, N. (1995). Solubilization of Bamboo Grass Xylan by Steaming Treatment. Holzforschung, 49, 193-196.

Bobleter, O. (1994). Hydrothermal Degradation of Polymers Derived from Plants. Progress in Polymer Science, 19(5), 797-841.

Carrasco, J.E., SaÂiz, M.C., Navarro. A., Soriano, P., SaÂez, F., \& MartõÂnez, J. M. (1994). Effects of Dilute Acid and Steam Pretreatments on The Cellulose Structure and Kinetics of Cellulosic Fraction Hydrolysis by Dilute Acids in Lignocellulosic Materials. Applied Biochemical and Biotechnology, 45-46(1), 23-34.

Carvahlo, D, M, D. Jose, H, D, Q., \& Jorge, L, C. (2017). Hydrothermal and Acid Pretreatment Improve Ethanol Production from Lignocellulosic Biomasses. BioResource, 12(2), 3088-3017.

Costa, A. G., Pinheiro, G. C., Pinheiro, F. G. C., Dos Santos, A. B., Santaella, S. T., \&Leitão, R. C. (2014). The Use of Thermochemical Pretreatments to Improve The Anaerobic Biodegradability and Biochemical Methane Potential of The Sugarcane Bagasse. Chemical Engineering Journal, 248, 363-372.
Garrote, G., DomõÂnguez, H., \& Parajo, J. C. (1999). Hydrothermal Processing Of Lignocellulosic Materials. Holz. Roh. Werkst. 57, 191-202.

Gírio, F. M., Fonseca, C., Carvalheiro, F., Duarte, L.C., Marques, S., \& BogelLukasik, R. (2010). Hemicelluloses for Fuel Ethanol: A Review. Bioresource Technology, 101(13), 4775-4800.

Hage, R. E., Chrusciel, L., \& Desharnais, L. (2010). Effect of Autohydrolysis of Miscanthus Giganteus on Lignin Structure and Organosolv Delignification. Bioresource Technology, 101, 9321-9329.

Hu, F., Jung, S., \& Ragauskas, A. (2012). Pseudo-Lignin Formation and Its Impact on Enzymatic Hydrolysis. Bioresources Technology, 117, 7-12.

Ibbett, R., Gaddipati, S., Hill, S., \& Tucker, G. (2013). Structural Reorganisation of Cellulose Fibrils in Hydrothermally Deconstructed Lignocellulosic Biomass and Relationships with Enzyme Digestibility. Biotechnology Biofuel, 6, 1-33.

Jin, S. G., Zhang, G. M., Zhang, P. Y., Li, F., Fan, S. Y. \& Li, J. (2016). Thermochemical Pretreatment and Enzymatic Hydrolysis for Enhancing Saccharification of Catalpa Sawdust. Bioresource Technology, 205, 34-39.

Lei, H. W., Cybulska, I. \& Julson, H. (2013). Hydrothermal Pretreatment of Lignocellulosic Biomass and Kinetics. Journal of Sustainable Bioenergy Systems, 3, 250-259.

Marshall, W. L. (1981). Ion Product of Water Substance, $0-1000^{\circ} \mathrm{C}$, 110,000 Bars New International Formulation and Its Background. Journal Physical and Chemical Reference Data, 10(2), 295-304.

Moiser, N., Charles, W., Bruce, D., Richard, E., Lee, Y. Y., Mark, H., \& Michael, L. (2005). Features of Promising Technologies for Pretreatment of Lignocellulosic 
Biomass. Bioresource Technology, 96, 673-686.

Mood, S.H., Golfeshan, A.H., Tabatabaei, M., Jouzani, G.S., Najafi, G.H., Gholami, M. \& Ardjmand, M. (2013). Lignocellulosic Biomass to Bioethanol, A Comprehensive Review With A Focus on Pretreatment. Renewable and Sustainable Energy Reviews, 27, 7793.

Ninomiya, K., Ohta, A., Omote, S., Ogino, C., Takahashi, K., \& Shimizu, N. (2013). Combined Use of Completely Bio-Derived Cholinium Ionic Liquids and Ultrasound Irradiation for The Pretreatment of Lignocellulosic Material to Enzymatic Saccharification. Chemical Engineering Journal, 215-216, 811818.

Nitsos, C. K., Matis, K. A., \& Triantafyllidis, K. S. (2013). Optimization of Hydrothermal Pretreatment og Lignocellulosic Biomass in the Bioethanol Production Process. ChemSusChem, 6(1), 110-122.

O'Sullivan, A. C. (1997). Cellulose: The Structure Slowly Unravels. Cellulose, 4, 173-207.

Oh, S. Y., Yoo, D. J., Shin, Y., \& Seo, G. (2005). FTIR Analysis of Cellulose Treated with Sodium Hydroxide and Carbon Dioxide. Carbohydrate Research, 340, 417-428.

Petchpradap, P., Yoshida, T., Charinpanitkul, T., \& Matsumura, Y. (2009). Hydrothermal Pretreatment of Rubber Wood for the Saccarification Process. Industrial and Engineering Chemistry Research, 48(9), 45874591.

Reza, M. T. (2013). Upgrading Biomass by Hydrothermal and Chemical Conditioning (Thesis).Reno: University of Nevada.

Ruiz, E., Cara, C., Manzanares, P., Ballesteros, M., \& Castro, E. (2008). Evaluation of Steam Explosion
Pre-Treatment for Enzymatic Hydrolysis of Sunflower Stalks. Enzyme and Microbial Technology, 42(2), 160-166.

Sarwono, R., Arief, H., Rizka, P., Hendris, H, K., \& Fatah, S. (2016). Konversi Limbah Tandan Kosong Kelapa Sawit Menjadi Glukosa dengan Proses Hidrotermal Tanpa Melalui Proses Pretreatment. Biopropal Industri. 7(2), 63-71.

Sasaka, M., \& Ozer, E. (1995). Aqueous Extraction of Sugarcane Bagasse Hemicellulose and Production of Xylose Syrup. Biotechnology anad Bioengineering, 45, 517-523.

Shuai, L., Yang, Q., Zhu, J. Y., Lu, F. C., Weimer, P. J., Ralph, J., \& Pan, X. J. (2010). Comparative Study of SPORL and Dilute-Acid Pretreatments of Spruce for Cellulosic Ethanol Production. Bioresources Technology, 101, 31063114.

Smeets, E. M. W., Faaij, A. P. C., Lewandowski, I. M., \& Turkenburg, W. C. (2007). A Bottom-Up Assessment and Review of Global Bio-Energy Potensials to 2050. Progress in Energy and Combustion Science, 33, 56-106.

Sun, T. S., Wang, K., Yang, G. H., Yang, H.Y., \& Xu, F. (2014a). Hydrothermal Treatment and Enzymatic Saccharification of Corncobs. Bioresources, 9(2), 3000-3013.

Sun, S. N., Cao, X. F., Li, H.Y., Xu, F., \& Sun, R. C. (2014b). Structural Characterization of Residual Hemicelluloses from Hydrothermal Pretreated Eucalyptus Fiber. International Journal of Biological Macromolecules, 69, 158-164.

Tortosa, J. F., Rubio, M., \& Demetrio, G. (1995) Autohidroâlisis De Tallo De Maõâz En Suspensioân Acuosa. Anidad. 52: 181-188.

Tune, M. S., \& Heiningen, A. R. P. (2011). Characterization and Molecular 
Weight Distribution of Carbohydrates Isolated from The Autohydrolysis Extract of Mixed Southern Hardwoods. Carbohydrate Polymer, 83, 8-13.

Wahyudiono, W., Machmudah, S., \& Goto, M. (2013). Utilization of Sub and Supercritical Water Reactions in Resource Recovery of Biomass Wastes. Engineering Journal, 17(1), 1-12.

Wu, M., Zhao, D. H., Phang, J. H., Zhang, X. M., Li, M. F., Xu, F., \& Sun, R. C. (2015). Separation and Characterization of Lignin Obtained by Catalytic Hydrothermal Pretreatment of cotton Stalk. Industrial Crops and Products, 66, 123-130.

Xiao, X., Bian, J., Li, M.F., Xu, H., Xiao, B., \& Sun, R. C. (2014). Enhanced Enzymatic Hydrolysis of Bamboo (Dendrocalamus giganteus Munro) Culm by Hydrothermal Pretreatment. Bioresource Technology, 159, 4147.

Zhao, J., Quan, C. S., \& Fan, S. D. (2013). Role of Lignin in Bio-Ethanol Production from Lignocellulosic Biomass. Journal of Biobased Materials and Bioenergy, 7(5), 533540. 